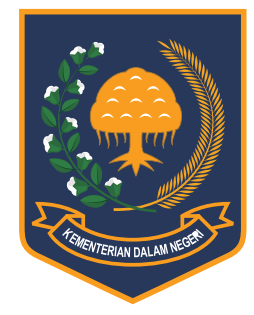

Jurnal Bina Praja 9 (1) (2017): 41-52

Jurnal Bina Praja

e-ISSN: 2503-3360 | p-ISSN: 2085-4323

Accreditation Number

735/AU2/P2MI-LIPI/04/2016

http://jurnal.kemendagri.go.id/index.php/jbp/index

\title{
Mapping the local OWn Resources (PAD) Performance AND REGIONAL DEPENDENCE IN INDONESIA 2008-2014: QUADRANT METHOD APPROACH
}

\author{
Joko Tri Haryanto * \\ Center for Climate Change Financing and Multilateral Policy, Fiscal Policy Agency \\ Ministry of Finance \\ R.M. Notohamiprodjo Bld, 5th Flr, Dr. Wahidin No. 1 Jakarta, 10710, Indonesia
}

Received: 20 December 2016; Accepted: 6 April 2017; Published online: 31 May 2017

DOI: $\underline{10.21787 / j b p .09 .2017 .41-52}$

\begin{abstract}
Fiscal decentralization reform era started since January 1st, 2001, with the implications of changes from centralized to highly decentralized. Unfortunately, it led to a greater dependence on the Local Government to Central Government through the Intergovernmental Transfers, especially on General Allocation Fund (DAU) and also a few on the Specific Allocation Fund (DAK) and Revenue Sharing (DBH). Based on that problem, this research aims to describe regional performances since 2008 until 2014, using several indicators and quadrant method approaches. In accordance with the calculation of the ratio of local independence, the majority of regions are in the category of less independent. While using dependency ratio, the majority of regions are in the group of very large dependency and a dependency. From the results of quadrant analysis methods, most regions are in quadrant III, which means to have a high dependence on government assistance. As a policy recommendation, the government needs to evaluate the improvement of the fiscal decentralization in Indonesia.
\end{abstract}

Keywords: Local Own Resources (PAD), Local Dependency, Local Independency, Quadrant Method

\section{INTRODUCTION}

The implementation of fiscal decentralization in Indonesia's reformation era officially begins on January 1st, 2001. It is also associated with the transformation process into a decentralized authority from the centralized system. Ratification Law of the Republic of Indonesia Number 22 of 1999 on Regional Administration and Law of the Republic of Indonesia Number 25 of 1999 on Financial Balance between Central and Local Government also gave a new paradigm by putting the full, comprehensive, and accountable autonomy to local and cities (Mardiasmo, 2002).

To support the success of fiscal decentralization, according to Cheema, Rondinelli, \& United Nations Centre for Regional Development (1983), the four essential elements given to the local governments include political, fiscal, administrative and economic decentralization. Those elements are the obligation of local governments to manage efficiently and effectively. In other words, fiscal decentralization also marks a new era in the development of a region to manage and use all available resources for the creation of prosperity and progress together (Rahman, Naukoko, \& Londah, 2014).

As we know that the local fiscal autonomy is one of the most important aspects of the implementation of local decentralization (Muryawan \& Sukarsa, 2016). It's caused by the presence of a definition of local fiscal autonomy which illustrates the ability of local governments to improve the Local Own Resources (PAD) either through local taxes, levies and other legitimate PAD (Basri, Syaparudin, \& Junaidi, 2013). The same thing also delivered by Halim (2001) which states that the local fiscal decentralization can be reached if accompanied by a delegation of effective financial and local governments are financially able to be independent

\footnotetext{
* Corresponding Author

Phone : +62817 6069905

Email : Djohar78@gmail.com
} 
from the central government.

Another factor is the local capability in managing regional finances. The ability will affect the fate of the region itself. An area can be strong and powerful as well as develop its greatness or just become powerless is largely determined by the quality of public financial management (Arianda, Nurazlina, \& Hasan, 2014). Therefore, the area of financial management issues become very crucial and must be considered carefully. According to Koeswara (2016), he also considered planning and budgeting process. He mentioned that a process is very crucial related to the achievement of local government goals. The output of the integrated planning process in the context of local government is the Local Budget (APBD).

This issue becomes very important related to the structure and characteristics of the local government in Indonesia. On the general condition, which can be divided into 1) local government that is abundant in natural resources; 2) local government with high sources of taxation base; 3 ) local government that does not have the wealth of the area at all (Suprantiningrum, 2015).

At the beginning, the implementation of fiscal decentralization in Indonesia is driven more by the issue of bureaucracy reform and attempts to create local self-reliance (Sugiyanto, 2000) . Meanwhile, according to Rasyid (2002), the implementation of regional autonomy in the economic context as an expansion of opportunities for communities and local government to pursue prosperity and promote them. Widjaja (2004) provides more explanation about the purpose of fiscal decentralization, which is to achieve efficiency and effectiveness in public service.

On the other hand, many studies actually provide different finding. For example, Setiaji \& Adi (2007) found that the realization of regional autonomy shows symptoms of local large fiscal dependency against the central government. Research conducted by Bappenas on expenditure budget of the provincial government in 2001 and 2002 also supported this hypothesis.

Some rich local government with natural resources also have their own problem when they can't manage properly their financial sources (Bauer, Rietveld, \& Toledano, 2014). In fact, from all provinces, there are only seven provinces with higher fiscal capacities, namely Bali, Banten, South Sumatra, Yogyakarta, West Sumatra, West Kalimantan, and South Sulawesi (Maryono \& Nurhayati, 2013).

Whereas the financial management capacity greatly affects the strategic capabilities of public institutions in improving their financial income (Harriss-White, 1997). And precisely these limitations caused by market failures and barriers that distort macro government bureaucracy perception (Sunaryo \& Cicellia, 2014).

In other ways, Sasana (2015) proved that decentralization has a positive effect on economic growth and macroeconomic stability in all provinces in Indonesia. Furthermore, Apriesa \& Miyasto (2013) proved that decentralization can support the economic growth in Central Java Provinces. In another research, the same finding is also expressed by Yuana (2014) that fiscal decentralization has a positive direction towards the economic growth in Indonesia.

The increase of PAD can also boost the capital formation in some areas. Prasetyaningtyas (2013) found in East Java that there is a relation between capital spending and fiscal decentralization, in which municipal/district will increase their capital spending during the local election.

In theory, the PAD itself has a role as a budgeter and regulator. Budgeter functions interpreted that $\mathrm{PAD}$ as a means to fill the government's coffers to finance government activities and development. While the regulator function means that the PAD is used as a tool to organize efforts in achieving a particular goal such as reducing the consumption of goods that are considered negative or a taxation service to avoid a scarcity of products circulating domestically (Adisasmita, 2011).

In many cases, to increase revenue can be done by referring to sectoral capabilities of each region. However, strived for the development of the sector aimed at improving the PAD is also aligned with the goal of preserving the environment, particularly those with a significant impact, for example, the tourism sector in some regions premier tourist destination. Thus, the region will get a double benefit from the existence of such activities (Imron, 2015).

It is frequently discussed on several occasions as the concept of decoupling economic development which implementation does not only create wealth alone but also maintain and mitigate the negative impacts that will be executed according to sustainable principles. It should be understood that in any construction activity, in addition to primary products generated by-products, it requires a treatment that does not produce externalities (Aulia, 2015).

Some experts then tried to construct the main characteristics of regions that are considered capable of implementing fiscal decentralization. Based on Halim, 2001 in (Vurry, Suwendra, \& Yudiaatmaja, 2014), some of the main features of the area that is able to run a fiscal decentralization including: 1) the area should be able to have the authority and the ability to explore the sources of finance, manage, and use their own finances that are adequate to finance organization of government 
and 2) dependence on central assistance should be as minimal as possible so that PAD can be part of the largest financial resources so that the role of local government become bigger anyway.

The demand to increase of PAD is also in line with the enlargement authority function delegated to local governments. Especially in the early period of fiscal decentralization, the government also made a devolution mechanism of personnel, equipment, and documentation (P3D) to the region in a large scale (Herawati \& Supratiwi, 2013).

In a way, the contribution of PAD can be viewed as an indicator or criteria for measuring the dependency on the central area. The bigger the contribution of PAD in an area, it will reduce the degree of dependence on central assistance. Conversely, the smaller contribution of PAD to APBD the local dependence, central assistance will increase (Sandri, Putri, \& Dwirandra, 2016).

One thing to keep in mind is that the mobilization of financing sources within certain limits can improve financial performance area. But in excessive levels, it will cause long-term nonproductive effects (Efendi \& Wuryanti, 2011). The diversity of potential and resources in some areas are potentially creating gaps in the reception of PAD. Therefore, efforts should be made thoroughly to neutralize these effects.

The implementation of decentralization also marks a new era of political relations between the Central Government and the Regions after previously considered to be very centralized. It was stated by Pratikno (2005) which states that the pattern of central and local relations in the New Order era is a centralized pattern of relationships. This centralized pattern of relationships makes the central government dominates all sides of governance, including a financial balance of the relationship patterns.

An interesting opinion is also delivered by Rondinelli (1981) which states that decentralization can be interpreted as a political transfer process. This is in accordance with the purpose of the implementation of decentralization and regional autonomy in Indonesia through money by following function principle, although in some other countries the process of decentralization is limited on delivery financing sources (Leemans, 1970). Neither stated by Lay (2003) who analogized decentralization as a political and administrative decentralization process that produces local state government in the form of administrative areas.

Oates (1993) through the decentralization theorem states that the fundamental economic efficiency can be improved by delegates in the form of fiscal decentralization to the government at the lowest level, which causes an increase in economic growth, both at national and regional level. Through this theory, Oates emphasized the analysis on aspects of cost efficiency due to the delegation of authority that would eliminate the bureaucracy. This chain bureaucracy has often been considered to be a source of high-cost economy.

The same perception conveyed by Tiebout (1956) which states that the fundamental ideas behind the implementation of fiscal decentralization are: 1) through the implementation of fiscal decentralization, the economic efficiency can be improved through a better public services; 2) competition in the provision of public services and inter-regional population mobility will occur in order to adjust the preferences between communities and local government.

Format fiscal decentralization in Indonesia is on its way to getting better. If the previous financial balance mechanism of the relationship between the Central Government and Local Government conducted within the framework of the autonomous regional subsidy mechanism (SDO) and the funds of President's instruction (Inpres), then in the reform era relationship format turned into a Transfer to Regions mechanism (Amarullah, 2013).

Under Law of the Republic of Indonesia Number 33 of 2004 on Financial Balance between Central and Local Government, the Regional Transfer mechanism consists of the allocation of Fund Balance (Daper) and Special Autonomy and Adjustment Fund. Fund balance itself is divided into Revenue Sharing (DBH), General Allocation Fund (DAU), and Specific Allocation Fund (DAK). This is in accordance with the implementation of the money follows function principle (Zulkarnain, 2014).

Regional financial performance measurements often become major benchmarks of success in local government management. Local government performance is then defined by the Study Team on the Development of Performance Accountability System for Government in Soleh \& Suripto (2011) as an illustration of the level of achievement in the implementation of an activity/program/policy in achieving the goals, objectives, mission, and vision of the organization as stated in the formulation of strategic planning of an organization.

Based on these definitions, the assessment of the performance of the local government became significant in ensuring accountability of Regional Head of the people who had elected him. The assessment also will expand the dimensions, not just an assessment of the achievement of the targets planned program but also extends to the use of economic resources efficiently and effectively.

Research by Halim (2001) adds that among the overall assessment of the local government performance, rating performance and financial capability of the area to be one of the crucial things. This study also adds that the analysis of 
the performance and ability of local finance is the attempt to identify the characteristics of finance based on financial statements that are available.

Other researchers, Wihana (2010) states that the policy of decentralization and regional autonomy, not only has changed the rules in relation to central and local government finances drastically but also change the pattern of organizational behavior, human resource policies and actors.

Under Law of the Republic of Indonesia Number 32 of 2004 and its revision Law of the Republic of Indonesia Number 23 of 2014 then followed by Law of the Republic of Indonesia Number 28 of 2009 on Regional Tax and Regional Retribution from APBD comprised of Local Own Resources (PAD) includes local taxes, retribution, and other PAD and Transfer to Region. Local own resources (PAD) often used as key indicators of Regional Financial Independence valuation as well as the effort to reduce fiscal budget (APBD) dependency.

Post-publication of these regulations, a number of areas and then demonstrate significantly increased the capacity of its own local own resources (PAD). However, the creativity and initiative of the local government in strengthening the capacity of local own resources (PAD) also have to continue to be controlled, not only because the issuance of local taxes mechanism that are close list, but also to avoid the creation of a business climate that is not conducive (Herawati \& Supratiwi, 2013).

The types of provincial taxes are close or limited which means the province cannot collect or create the kind of levy or other taxes beyond those already established and can only increase the types of levies in accordance with the criteria specified in the Act. Conversely, those types of taxes in the districts/cities are not close list or limited so that each district/city has the opportunity to explore the potential of their own financial resources beyond the defined explicitly in the Act.

In the local own resources (PAD) management, in particular, relating to components of local taxes, some principles need to be considered by the Local Government. Thus, the creation of sources of the budget (APBD) is not contrary to the principle of efficiency and supporting the local investment climate. According to the Devas in Mahmudi (2010), some of the main principles of the local taxation are:

1. The principle of elasticity where the local tax mechanism must provide sufficient income and elastic, easily up and down with the increase or decrease of income levels;

2. The principle of fairness, which means the local tax must feed that sense of justice, both vertically according to their social group, community and horizontally equitable, which means the same for every member of society;

3. The principle of convenient administrative where management of regional taxes administration should be flexible, simple, easily calculated, and provide satisfactory services to the taxpayer;

4. The principle of political acceptance, which means the local tax must be accepted politically by the public so they are aware of their obligations to pay;

5. The non-distortion principle on the economy in which local taxes that applied must not have a negative impact on the economy.

Unfortunately, as mentioned in Haryanto (2016) despite the positive impact of fiscal decentralization in Indonesia, it is also considered creating an impact of the growing dependence of the regions to a central government. It can be seen from the increasing amount of allocation to the Regional Transfer annually. According to the Central Budget Report, in 2008, the amount allocated to the Transfer to the Region almost IDR292,4 trillion and has been increased to IDR770,2 trillion in 2016 budget year, with the addition of the allocation of the Village Fund since 2015.

Based on this introduction, the problem statement on this research is how the mapping of the PAD performance in Indonesia fiscal decentralization era fro 2008-2014 and also how is the analysis of regional dependency ratio? Different sizes of ratio, which are used in this study, are the local fiscal independence ratio and dependence ratio.

The research by Saputra (2013) stated that the definition of independency ratio is the financial capability to finance its own local government activities, development, and service to the people who have paid taxes and levies as a source of revenue required by the region. While the research by Desita (2015) stated that the definition of regional fiscal dependency ratio is an indicator that described how big the revenue (APBD) dependency level from the Central Government. This ratio also describes the performance of the budget independently.

To limit this study, the researcher focuses the analysis from 2008 to 2014, due to the difficulty of getting more contemporary data sources. Another limitation is related to the number of variables that used only local own resources (PAD), total revenue and total transfer to the region. The analysis was also limited to the ratio of local independence and dependence.

\section{METHOD}

In accordance with the research approach, this study used descriptive research to address a number of variables relating to the research problem. Types of variables selected in this study are the local own resources (PAD) variable, total revenue, and total 
Table 1.

Patterns of Central and Local Government Relations

\begin{tabular}{cccc} 
Ratio & Local Independency & Local Fiscal Dependency & Relationship Pattern \\
$\leq 25$ & Unable & Very small & Instructive \\
\hline $25-50$ & Less Independent & Good Enough & Consultative \\
\hline $51-75$ & Independent Enough & Large Enough & Participatory \\
\hline $76-100$ & Already Independent & Very Large & Discretionary \\
\hline
\end{tabular}

Source: Halim, 2001

revenue transfer to the region. It is assumed that there is a relationship between the variables of local own resources (PAD), total local revenues, as well as transfers to the regions in influencing independence and dependence of local fiscal indicators from the calculation of the hypothesis, which then will be used as the basis for formulating recommendations and evaluation of fiscal decentralization policy in the future.

Analysis method used was ratio analysis method by comparing the ratio of local own resources (PAD) to total revenue transfers to the region as a depiction of the local independent level (TKD) and transfer revenue ratio to total local revenues as a depiction of the level of local dependency (TKtD). In general formula ratios used are:

\section{Level of Local Independency (TKD)=PAD/TPT}

Where TKD is Level of Local Independency, PAD is the Local Revenue and TPT is Total Revenue Transfer;

\section{Level of Local Dependency $\left(\mathrm{TK}_{\mathrm{t}} \mathrm{D}\right)=\mathrm{PT} / \mathrm{TPD}$}

Where TKtD is Level of Local Dependency, PT is the Transfer Admission and TPD is Total Local Revenue;

Local independence ratio (TKD) and the local dependency ratio (TKtD) will be used as the basis of the analysis in the evaluation to all districts/cities and provinces in Indonesia from 2008 to 2014. As for the meaning of the region's autonomy and dependency ratios will use the reference of Paul Harsey and Kenneth Blanchard in Halim (2001) as described in Table 1.

Overall the type of data used in this research is secondary data obtained from official agencies of Directorate General of Fiscal Balance (DJPK), Ministry of Finance and the Ministry of Internal
Affairs. While the population of this study done to all districts/cities and provinces throughout Indonesia. From the results of local independence ratio (TKD) and the regional dependency ratio (TKtD) is then mapped into Quadrant analysis method that divides the area into four quadrants.

Quadrant analysis method in 2003 was used as one of the tools by Bappenas in to ask questions of local financial ability (Samora, 2010). The first quadrant describes the independent region with a low degree of dependence. The second quadrant depicts dependent regions and low level of dependence. While the third quadrant describes a region dependent and high level of dependence while the fourth quadrant describes an independent region with a high level of dependency.

\section{RESULTS AND DisCUSSION}

Fiscal decentralization implementation in Indonesia reformation era officially begins on January 1st, 2001. The policy implications are widespread, particularly in regard to political relations between central and local government administration. Centralized relationships became decentralized. Ratification Law of the Republic of Indonesia Number 22 of 1999 on Regional Administration and Law of the Republic of Indonesia Number 25 of 1999 on Financial Balance between Central and Local Government also created a new paradigm by putting the full autonomy, comprehensive and accountable to the district and the city.

To support the successful implementation of this fiscal decentralization, the government has to give up some authority to regional governments with appropriate sources of financing money follows function principle. By putting in the hands of local government authority, expected quality of public services is on the rise because it is assumed they are more aware of what the needs. On the other hand, the implementation of fiscal decentralization is also 
expected to increase the level of independence in their respective areas.

Unfortunately, many studies actually provide the phenomenon of different things from the implementation of the fiscal decentralization. In the implementation, many people feel that fiscal decentralization would indicate the emergence of symptoms of a greater dependence on the region on the central government. This clearly demonstrates the helplessness of local own resources (PAD) in financing budget expenditures in the area. The demand for the growing local revenue also increased in line with the enlargement function of the authority delegated to the regions.

Therefore, it is necessary to have a productive creativity and initiative from the region to explore the sources of financing that comes from local own resources (PAD) within the boundaries of the regulations that have been defined. One thing to keep in mind is that the mobilization of financing sources within certain limits can improve financial performance area. The diversity of potential and resources in some region potentially create gaps in local own resources (PAD).

Therefore, efforts should be made in order to neutralize these effects. One of the efforts that need to be done is the need to compile the mapping performance of local own resources (PAD) in the area as well as analyzing the level of regional dependency on central assistance. Results of mapping the performance of local own resources (PAD) and analysis dependence level on the central area are then organized into a diagram using the quadrant method.

\section{A. Independence and Dependence Local Indicators}

In general, the result of calculation of local independency ratio and fiscal dependency across Indonesia from 2008 to 2014 can be seen in Table 2 .

Based on Table 2, the calculation results of local independence indicators can be divided into three groups, namely the less independent, independent enough and unable. List of regions that fall within the categories are:

1. Less independent: the majority of regions in fiscal decentralization era is in the less independent group. There are about 29 areas of 34 provinces with total districts/cities that fall into this category or reach nearly $85 \%$ of the total. Regions with less independent category is generally defined as areas with independency ratio between 25 to 50 as well as the central and local government relations pattern is consultative;

2. Quite independent: in this group, there

Table 2.

Calculation of Local Independency and Dependency

\begin{tabular}{|c|c|c|c|c|}
\hline No & Region & Local Independency & $\begin{array}{l}\text { Local Fiscal } \\
\text { Dependency }\end{array}$ & Relationship Pattern \\
\hline 1 & Aceh & Less Independent & Quite Large & Consultative \\
\hline 2 & North Sumatra & Less Independent & Quite Large & Consultative \\
\hline 3 & West Sumatra & Less Independent & Quite Large & Consultative \\
\hline 4 & Riau & Less Independent & Very Large & Consultative \\
\hline 5 & Riau Islands & Less Independent & Quite Large & Consultative \\
\hline 6 & Jambi & Less Independent & Very Large & Consultative \\
\hline 7 & South Sumatra & Less Independent & Very Large & Consultative \\
\hline 8 & Bangka Belitung Islands & Less Independent & Very Large & Consultative \\
\hline 9 & Bengkulu & Less Independent & Very Large & Consultative \\
\hline 10 & Lampung & Less Independent & Quite Large & Consultative \\
\hline 11 & Jakarta & Quiet Independent & Quite Good & Participatory \\
\hline 12 & West Java & Quiet Independent & Quite Large & Participatory \\
\hline 13 & Banten & Quiet Independent & Quite Large & Participatory \\
\hline
\end{tabular}




\begin{tabular}{|c|c|c|c|c|}
\hline No & Region & Local Independency & $\begin{array}{l}\text { Local Fiscal } \\
\text { Dependency }\end{array}$ & Relationship Pattern \\
\hline 14 & Central Java & Less Independent & Quite Large & Consultative \\
\hline 15 & Yogyakarta & Less Independent & Quite Large & Consultative \\
\hline 16 & East Java & Less Independent & Quite Large & Consultative \\
\hline 17 & West Kalimantan & Less Independent & Very Large & Consultative \\
\hline 18 & Central Kalimantan & Less Independent & Very Large & Consultative \\
\hline 19 & South Kalimantan & Less Independent & Quite Large & Consultative \\
\hline 20 & East Kalimantan & Less Independent & Quite Large & Consultative \\
\hline 21 & North Kalimantan & Unable & Quite Good & Instructive \\
\hline 22 & North Sulawesi & Less Independent & Very Large & Consultative \\
\hline 23 & Gorontalo & Less Independent & Very Large & Consultative \\
\hline 24 & Central Sulawesi & Less Independent & Very Large & Consultative \\
\hline 25 & South Sulawesi & Less Independent & Quite Large & Consultative \\
\hline 26 & West Sulawesi & Less Independent & Very Large & Consultative \\
\hline 27 & Southeast Sulawesi & Less Independent & Very Large & Consultative \\
\hline 28 & Bali & Quiet Independent & Quite Good & Participatory \\
\hline 29 & West Nusa Tenggara & Less Independent & Quite Large & Consultative \\
\hline 30 & East Nusa Tenggara & Less Independent & Very Large & Consultative \\
\hline 31 & Maluku & Less Independent & Very Large & Consultative \\
\hline 32 & North Maluku & Less Independent & Very Large & Consultative \\
\hline 33 & Papua & Less Independent & Quite Large & Consultative \\
\hline 34 & West Papua & Less Independent & Quite Large & Consultative \\
\hline
\end{tabular}

Source: MOF, 2015, processed data

were about 4 areas namely Jakarta, West Java, Banten and Bali Province. Regions with an independent category is a group with independency ratio about 51-75 and the central and local government relations pattern is participatory;

3. Unable: there is only one area that falls into this category, it is North Kalimantan province. The area with unable category defined that the independency ratio is less than or equal to 25 . For this unable region, the relationship pattern is instructive with the dominant role of the Central Government. One factor that may cause the influx of North Kalimantan province into this group is a factor of regional expansion;
The phenomenon where there were still many regions that fall into the less independent category while implementing fiscal decentralization in Indonesia is nearly 16 years, seems necessary to get serious attention from the government. The initial goal of fiscal decentralization in order to create local independency aspect has even become further from expectation. For this reason, the evaluation and monitoring mechanism shall be strengthened and follow the money follows function principle. Reward and punishment must be fully implemented in and the fund allocation to the regions needs to be sharpened.

While in local dependency ratio analysis, based on Table 2 can be divided into very small, quite 
Table 3.

Quadrant Analysis

\begin{tabular}{|c|c|c|}
\hline Description & $\mathrm{TK}_{\mathrm{t}} \mathrm{D}_{\mathrm{i}}>\mathrm{TK}_{\mathrm{t}} \mathrm{D}$ & $\mathrm{TK}_{\mathrm{t}} \mathrm{D}_{\mathrm{i}}<\mathrm{TK}_{\mathrm{t}} \mathrm{D}$ \\
\hline \multirow[t]{2}{*}{$\mathrm{TKD}_{\mathrm{i}}>\mathrm{TKD}$} & Lampung, East Kalimantan & $\begin{array}{c}\text { Aceh, North Sumatra, Jakarta, Banten, } \\
\text { West Java, Central Java, Yogyakarta, } \\
\text { East Java, South Kalimantan, South } \\
\text { Sulawesi, Bali, Papua, West Papua }\end{array}$ \\
\hline & (Quadrant IV) & (Quadrant I) \\
\hline TKD $_{i}<$ TKD & $\begin{array}{l}\text { West Sumatra, Riau, Riau Islands, } \\
\text { Jambi, South Sumatra, Bangka Belitung } \\
\text { Islands, Bengkulu, West Kalimantan, } \\
\text { Central Kalimantan, North Sulawesi, } \\
\text { Gorontalo, Central Sulawesi, West } \\
\text { Sulawesi, Southeast Sulawesi, West } \\
\text { Nusa Tenggara, East Nusa Tenggara, } \\
\text { Maluku, North Maluku }\end{array}$ & North Kalimantan \\
\hline & (Quadrant III) & (Quadrant II) \\
\hline
\end{tabular}

Source: MOF, 2015, data processed

Where:

$\mathrm{TKD}_{\mathrm{i}} \quad$ : Level of local independence $\mathrm{i}$;

$\mathrm{TKtD}_{\mathrm{i}} \quad$ : Level of regional dependency to $\mathrm{i}$;

TKD : Average level of the regional autonomy;

$\mathrm{TK}_{\mathrm{t}} \mathrm{D} \quad$ : Average level of regions dependency. good, quite large and very large groups. Further explanations are as follows:

1. Very Large: in this group, there are about 15 areas or $47 \%$ of the total. These areas are the province of Riau, Jambi, South Sumatra, Bangka Belitung, Bengkulu, West Kalimantan, Central Kalimantan, North Sulawesi, Gorontalo, Central Sulawesi, West Sulawesi, Southeast Sulawesi, NTT, Maluku and North Maluku. Regions with a very large category of dependency ratios marked with the number ratio of about 76 100. This means that local fiscal dependence on central assistance is very large as well as the performance of their budgets is very bad;

2. Quite Large: there are about 16 areas in the group with local fiscal dependency ratio in is quite large. Quite large fiscal dependency group have a value of about 51 to 75 and is defined as a group area with local fiscal dependency large enough and local budget performance (APBD) is less good;

3. Quite Good: in this group, there are only three areas namely Jakarta, Bali, and North Kalimantan. The quite good category indicates that the dependence of local fiscal budget is quite small and its performance is good enough to support the implementation of development and public services in the area. To Jakarta and Bali, it is because the tax revenue base areas that are relatively capable. While North Kalimantan is due to the regional expansion;

Actually, there is one more criteria namely the area with very little fiscal dependency ratio with a value less than or equal to 25 . Unfortunately, from all regions in Indonesia, none of which fall into this category. In the future, this condition is certainly a challenge that must be addressed together. Existing regulatory infrastructure also supports this goal where areas with high fiscal capacity will not get the allocated funds from the Central Government anymore.

\section{1) Quadrant Method Analysis}

From the calculation of the ratio in local independence and dependence, regional classification can be analyzed again in the quadrant method that will be split into four quadrants. Explanation of quadrant analysis method can be seen in Table 3.

Based on the description in Table 3, the total area in Indonesia can then be classified into 4 quadrants with the following explanation:

1. The area in quadrants I: consists of Aceh, North Sumatra, Jakarta, Banten, West Java, Central Java, Yogyakarta, East Java, South Kalimantan, South Sulawesi, Bali, Papua and West Papua. 
The whole area in the first quadrant can be interpreted as an independent local group with the level of regional fiscal dependence is relatively low;

2. The area in quadrant II: consists of the North Kalimantan. Quadrant II means that the area has not independent and the low level of dependence;

3. The area in quadrant III: consists of a group of West Sumatra, Riau, Riau Islands, Jambi, South Sumatra, Bangka Belitung Islands, Bengkulu, West Kalimantan, Central Kalimantan, North Sulawesi, Gorontalo, Central Sulawesi, West Sulawesi, Southeast Sulawesi, West Nusa Tenggara, East Nusa Tenggara, Maluku and North Maluku. This group is defined as the area that has not been independent and high level of fiscal dependency;

4. The area in quadrant IV: consists of Lampung and East Kalimantan. This area is classified as independent regional groups with high dependency rate.

Based on an analysis using the quadrant method in Table 3, things to be used as an in-depth evaluation are there were still large regional groups that fall into the quadrant III category. There are about 18 areas within the quadrant III. These areas are generally not independent and still have a high dependence on government assistance. Sources finance delivery of local taxation side looks like it needs to be reviewed because it has not impacted improve aspects of independency in the area. The review may be based on consideration of broadening the base of taxation or accuracy of taxation mechanisms existing in the area.

The good news is that many areas which also listed in quadrant I, which portray the independent areas with a low level of fiscal dependency. These conditions should be ideal conditions that must be achieved by the implementing fiscal decentralization and regional autonomy in Indonesia. This condition is the initial purpose of implementing fiscal decentralization. When the area is able to improve their independence, the function of public services in the area will also be increased in terms of quality.

\section{Conclusion}

As a conclusion, based on the calculation of the indicators in local independence, regional groups are classified into 1) Less independent of which about 29 regions from 34 total provinces along with districts/cities fall into this category or reach nearly $85 \%$ of the total. Regions with a less independent category are generally defined as areas with ratio independency between 25 to 50 as well as the relationship of central and local government pattern is consultative; 2) Quite independent with a group of about four areas namely Jakarta, West Java, Banten, and Bali Province. Regions in a quite independent category are regions with independency ratio of about 51-75 and the relationship patterns of the local and central government is participatory.

Next group 3) Unable is only one area that is North Kalimantan that fall into this category. The area with unable category defined as a region independency ratio less than or equal to 25 . For this unable area, the relationship pattern is instructive created by the dominant role of the Central Government. One factor that may form the cause of the influx of North Kalimantan in this group is a factor of regional expansion.

Meanwhile, based on local dependency ratio analysis, can be divided into groups: very small, quite good, quite large and very large. A list of local that fall within a very large group, there are about 15 or $47 \%$ of the total. Regions with a very large category of dependency ratios marked with the number ratio of about 76-100. This means that local fiscal dependence on central assistance is very large as well as the performance of their budgets is very bad. Next is a quite large group consisting of 16 regions. Quite large fiscal dependency group have a value of about 51 to 75 and is defined as a local group with a fiscal dependency that large enough and local budget performance (APBD) is less good.

Next is a quite good group that consists of three areas namely DKI Jakarta, Bali, and North Kalimantan. The pretty good group indicates that the dependence of local fiscal budget is quite small and its performance is good enough to support the implementation of development and public services in the area. To Jakarta and Bali, it is because the tax revenue base in the area is relatively capable. While North Kalimantan Province due to regional expansion so it is still a new region.

Actually, there is one more criteria namely the area with very little fiscal dependency ratio with a value less than or equal to 25 . Unfortunately, from all regions in Indonesia, none of which fall into this category. In the future, this condition is certainly a challenge that must be addressed together. Existing regulatory infrastructure also supports this goal where areas with high fiscal capacity did not get the allocated funds from the Central Government anymore.

By using the quadrant analysis, entire regions in Indonesia can then be classified into 4 quadrants comprising: a) Region in quadrants I: consisting of NAD, North Sumatra, Jakarta, Banten, West Java, Java Central, Yogyakarta, East Java, South Kalimantan, South Sulawesi, Bali, Papua and West Papua. The whole area in the first quadrant can be interpreted as an independent local group with the level of regional fiscal dependence is relatively low; b) Region in quadrant II: consists of the North 
Kalimantan. Quadrant II classified to a region that has not independent with the low level of dependence.

While the next group is c) Region in quadrant III: consists of a group of West Sumatra, Riau, Riau Islands, Jambi, South Sumatra, Bangka Belitung, Islands Bengkulu, West Kalimantan, Central Kalimantan, North Sulawesi, Gorontalo, Central Sulawesi, West Sulawesi, Southeast Sulawesi, NTB, NTT, Maluku and North Maluku. This group is defined as the dependent region with high level of fiscal dependency; and d) Region in quadrant IV: consists of Lampung and East Kalimantan. This area is classified as the independent regional group with high dependency rate.

As a recommendation, the government is obliged to observe the phenomenon where there are still many regions that fall into the category of less independent while implementing fiscal decentralization in Indonesia is nearly 16 years old after all, and it needs to get serious attention from the government. The initial goal of fiscal decentralization in order to create self-sufficiency aspect in the area even farther away from expectations. For this reason, the evaluation and monitoring mechanism shall be strengthened with money follows function principle. Reward and punishment in the true sense must be implemented in full and regions fund allocation needs to be sharpened.

Another recommendation is related findings using the quadrant method, where there are still large groups of areas that fall within the quadrant III. There are about 18 areas with the classification of quadrant III. These areas are generally not independent and still have a high dependence on government assistance. Delivery of financing source of local taxation still needs to be reviewed because it has not improved aspects of regional self-reliance. The review may be based on consideration of broadening the taxation base or accuracy of taxation mechanisms that existed in the region.

The obligation to support the success of fiscal decentralization in Indonesia is not only for the government to work alone. All elements of the nation must support and be active in their individual capacity. Academics and universities in the area can support the development of fiscal decentralization directly in the implementation of studies that are evaluative of fiscal decentralization itself. Capacity building for local government also needs to be a momentum for the role of academic and colleges in the area. Elements of society and non-governmental organizations should support the success in fiscal decentralization in the capacity of the catalyst that is not associated with personal or group interests.

\section{ACKNOWLEDGEMENT}

On this paper, the author will express his gratitude to the Fiscal Policy Agency (BKF) and Directorate General Fiscal Balance (DJPK) which have provided data for this study. And also many related stakeholders which have supported the implementation of research activities so that this study can be completed.

\section{REFERENCES}

Adisasmita, R. (2011). Pembiayaan Pembangunan Daerah. Yogyakarta: Graha Ilmu Publishing.

Amarullah, R. (2013). Desentralisasi Fiskal dan Pertumbuhan Ekonomi, serta Kaitannya dengan Otonomi Daerah. Jurnal Borneo Administrator, 9(3), 284-304. Retrieved from http://www.samarinda.lan.go.id/jba/index. php/jba/article/view/124

Apriesa, L. F., \& Miyasto. (2013). Pengaruh Desentralisasi Fiskal Terhadap Pertumbuhan Ekonomi Daerah dan Ketimpangan Pendapatan (Studi Kasus: Kabupaten/Kota di Jawa Tengah). Diponegoro Journal of Economics, 2(1), 1-12. Retrieved from http://ejournal-s1.undip.ac.id/ index.php/jme/article/view/1916

Arianda, G., Nurazlina, \& Hasan, H. M. A. (2014). Analisis Perkembangan Kemampuan Keuangan Daerah dalam Mendukung Pelaksanaan Otonomi Daerah di Kabupaten Natuna (Tahun Anggaran 2009-2013). JOM FEKON, 1(2), 1-15.

Aulia, N. F. (2015). Pemanfaatan Spent Resources dalam Mendukung Kegiatan Eco-economic Decoupling di Provinsi Jawa Tengah. Jurnal Bina Praja, 7(3), 261-270. http://doi. org/10.21787/jbp.07.2015.259-267

Basri, H., Syaparudin, \& Junaidi. (2013). Pemetaan Kinerja Pendapatan Asli Daerah dan Kemampuan Keuangan Daerah Kabupaten/ Kota di Provinsi Jambi. Jurnal Perspektif Pembiayaan Dan Pembangunan Daerah, 1(2), 81-90. Retrieved from http://online-journal. unja.ac.id/index.php/JES/article/view/1497

Bauer, A., Rietveld, M., \& Toledano, P. (2014). Managing the public trust: How to make natural resource funds work for citizens. (A. Bauer, Ed.). New York: Revenue Watch Institute $\&$ Vale Columbia Center.

Cheema, G. S., Rondinelli, D. A., \& United Nations Centre for Regional Development. (1983). Decentralization and Development: Policy Implementation in Developing Countries. Sage Publication, Inc.

Desita, P. N. (2015). Analisis Kemampuan Keuangan Daerah dalam Mendukung Pelaksanaan Otonomi Daerah Kota Pekanbaru (2010-2014). JOM FEKON, 2(2), 1-13.

Efendi, D., \& Wuryanti, S. (2011). Analisis 
Perkembangan Kemampuan Keuangan Daerah dalam Mendukung Pelaksanaan Otoda di Kabupaten Nganjuk. In Prosiding Seminar Nasional Ilmu Ekonomi Terapan 2011 (pp. 1-10). Lembaga Penelitian dan Pengabdian Kepada Masyarakat, Universitas Muhammadiyah Semarang. Retrieved from http://jurnal.unimus.ac.id/index.php/ psn12012010/article/view/400

Halim, A. (2001). Manajemen Keuangan Daerah: Bunga Rampai. Yogyakarta: UPP AMP YKPN.

Harriss-White, B. (1997). Informal Economic Order, Shadow States, private Status States, States of Last Resort and Spinning States: A Speculative Discussion Based on South Asian. Queen Elizabeth House, Working Paper Series. Retrieved from http://www.cs.odu. edu/ dlibug/ups/rdf/remo/qeh/qehwps/ qehwsp06.pdf

Haryanto, J. T. (2016). Regional Financial Performance Evaluation in the Indonesian Fiscal Decentralization. Bali.

Herawati, N. R., \& Supratiwi. (2013). Optimalisasi Pajak Daerah dalam Rangka Meningkatkan Kemampuan Keuangan Daerah. Jurnal Ilmu Sosial, 12(1), 41-67. Retrieved from http:// ejournal.undip.ac.id/index.php/ilmusos / article/view/10346

Imron, M. B. (2015). Meretas Jalan Meningkatkan Pendapatan Asli Daerah (PAD) melalui Desa Wisata Panglipuran Bali. Jurnal Bina Praja, 7(4), 279-288. http://doi.org/10.21787/ jbp.07.2015.279-288

Koeswara, H. (2016). The Optimization of Budget Outcome to Create Trust in Public Expenditure Allocation on Local Budget. Jurnal Bina Praja, 8(2), 277-291. http://doi.org/10.21787/ jbp.08.2016.277-291

Law of the Republic of Indonesia Number 22 of 1999 on Regional Administration, Pub. L. No. 22 (1999). Indonesia.

Law of the Republic of Indonesia Number 23 of 2014 on Regional Government, Pub. L. No. 23 (2014). Indonesia.

Law of the Republic of Indonesia Number 25 of 1999 on Financial Balance between Central and Local Government, Pub. L. No. 25 (1999). Indonesia.

Law of the Republic of Indonesia Number 28 of 2009 on Regional Tax and Regional Retribution, Pub. L. No. 28 (2009). Indonesia.

Law of the Republic of Indonesia Number 32 of 2004 on Regional Administration, Pub. L. No. 32 (2004). Indonesia.

Law of the Republic of Indonesia Number 33 of 2004 on Financial Balance between Central and Local Government, Pub. L. No. 33 (2004). Indonesia: 2004.
Lay, C. (2003). Otonomi Daerah dan Keindonesiaan. Yogyakarta: Pustaka Pelajar.

Leemans, A. F. (1970). Changing Patterns of Local Government. International Union of Local Authorities.

Mahmudi, Hardani, W., \& Sallama, N. I. (2010). Manajemen Keuangan Daerah. Jakarta: Erlangga.

Mardiasmo. (2002). Otonomi Daerah Sebagai Upaya Memperkokoh Basis Perekonomian Daerah. Jurnal Ekonomi Rakyat, 1(4), 1-14.

Maryono, \& Nurhayati, I. (2013). Kemampuan Keuangan dan Pajak Daerah Provinsi Jawa Tengah. In Proceeding Fakultas Ekonomi. Retrieved from https://www.unisbank.ac.id/ ojs/index.php/fe10/article/view/2812

Muryawan, S. M., \& Sukarsa, M. (2016). Pengaruh Desentralisasi Fiskal, Fiscal Stress, dan Kinerja Keuangan Daerah terhadap Pertumbuhan Ekonomi di Kabupaten/Kota Provinsi Bali. E-Jurnal Ekonomi Dan Bisnis, 5(2), 229-252. Retrieved from http://ojs.unud.ac.id/index. php/EEB/article/view/9379

Oates, W. E. (1993). Fiscal Decentralisation and Economic Development. National Tax Journal, 46(2), 237-243. Retrieved from https:// www.ntanet.org/NTJ/46/2/ntj-v46n02p23743 - fiscal-decentralization-economicdevelopment.html

Prasetyaningtyas, Y. N. (2013). Does Fiscal Decentralization Increase the Capital Spending on Infrastructure? Jurnal Ilmiah Administrasi Publik, 14(1). Retrieved from http:// ejournalfia.ub.ac.id/index.php/jiap/article/ view/318

Pratikno. (2005). Pengelolaan Hubungan Antar Pusat dan Daerah. Jakarta: LIPI Press.

Rahman, N. A., Naukoko, A., \& Londah, A. (2014). Analisis Perbandingan Kemampuan Keuangan Daerah di Provinsi Sulawesi Utara (Studi pada Kota Manado dan Kota Bitung. Jurnal Berkala Ilmiah Efisiensi, 14(3), 56-70. Retrieved from http://ejournal.unsrat.ac.id/index.php/jbie/ article/view/5462

Rasyid, M. R., \& Samah, K. (2002). Menolak Resentralisasi Pemerintahan: Draft Revisi UU No 22, 1999 Versi Depdagri. Jakarta: Diterbitkan untuk Masyarakat Ilmu Pemerintahan Indonesia.

Rondinelli, D. A. (1981). Government Decentralization in Comparative Perspective. International Review of Administrative Sciences, 47(2), 133-145. http://doi. org/10.1177/002085238004700205

Samora, R. (2010). Peta Kemampuan Keuangan Daerah pada Pemerintahan Kota dan Kabupaten Se-Jawa dan Bali Tahun 2004-2008: Metode Kuadran. Jurnal Akuntansi Kontemporer, 2(1), 
65-84. Retrieved from http://journal.wima. ac.id/index.php/JAKO/article/view/437

Sandri, N. K., Putri, I. G. A. M. A. D., \& Dwirandra, A. A. N. B. (2016). Kemampuan Alokasi Belanja Modal Memoderasi Pengaruh Kinerja Keuangan Daerah pada Indeks Pembangunan Manusia. Buletin Studi Ekonomi, 21(1), 71-81. Retrieved from http://ojs.unud.ac.id/index. php/bse/article/view/22301

Saputra, B. (2013). Pengaruh Desentralisasi Fiskal terhadap Pertumbuhan Ekonomi dan Kesejahteraan Masyarakat. Jurnal Borneo Administrator, 9(1), 96-111. Retrieved from http://samarinda.lan.go.id/jba/index.php/ jba/article/view/100

Sasana, H. (2015). Dampak Implementasi Desentralisasi Fiskal terhadap Pertumbuhan Ekonomi dan Stabilitas Harga di Provinsi di Indonesia. Media Ekonomi Dan Manajemen, 30(1), 1-14. http://doi.org/10.24856/mem. v30i1.230

Setiaji, W., \& Adi, P. H. (2007). Peta Kemampuan Keuangan Daerah Sesudah Otonomi Daerah: Apakah Mengalami Pergeseran? (Studi pada Kabupaten dan Kota Se-Jawa - Bali). In Simposium Nasional Akuntansi X2 (pp. 1-29). Makassar.

Soleh, C., \& Suripto. (2011). Menilai Kinerja Pemerintah Daerah. Bandung: Fokusmedia.

Sunaryo, B., \&Cicellia, C. (2014). Urgensi Peningkatan Kapasitas Pengelolaan Keuangan Daerah di Era Desentralisasi (Dinamika Pengelolaan Pajak Parkir Kecamatan Banguntapan, Kabupaten Bantul Provinsi DI Yogyakarta). Jurnal Bina Praja, 6(4), 293-306. http://doi. org/10.21787/jbp.06.2014.293-305
Suprantiningrum, S. R. (2015). Analisis Kinerja Pengelolaan Keuangan Daerah dan Tingkat Kemandirian Daerah di Era Otonomi Daerah (Studi Kasus Kota Semarang Tahun 20092013). Media Ekonomi Dan Manajemen, 30(1), 30-40. http://doi.org/10.24856/mem. v30i1.232

Tiebout, C. M. (1956). A Pure Theory of Local Expenditures. Journal of Political Economy, 64(5), 416-424. Retrieved from http://www. jstor.org/stable/1826343

Vurry, A. N., Suwendra, I. W., \& Yudiaatmaja, F. (2014). Analisis Kemampuan Keuangan Daerah Dan Trend pada Pemerintah Kabupaten Buleleng Tahun Anggaran 2004-2013. E-Journal Bisma Universitas Pendidikan Ganesha, 2(1). Retrieved from http://ejournal.undiksha. ac.id/index.php/JJM/article/view/4257

Widjaja, H. A. W. (2004). Otonomi Daerah dan Daerah Otonom. Jakarta: PT Raja Grafindo Persada.

Yuana, A. P. (2014). Analisis Kinerja Keuangan Daerah terhadap Pertumbuhan Ekonomi dan Ketimpangan Regional di Era Desentralisasi Fiskal (Studi Kabupaten/Kota di Provinsi Jawa Timur Periode 2008-2012). Jurnal Ilmiah Mahasiswa FEB Universitas Brawijaya, 2(2). Retrieved from http://jimfeb.ub.ac.id/index. php/jimfeb/article/view/1107

Zulkarnain. (2014). Analisis Keuangan Daerah Kabupaten Kubu Raya dalam Rangka Pelaksanaan Otonomi Daerah dan Faktorfaktor yang Mempengaruhinya. Jurnal Ekonomi Daerah (JEDA), 2(2). Retrieved from http:// jurnal.untan.ac.id/index.php/JEDA2/article/ view/6789 